\title{
DOI 10.26886/2414-634X.7(43)2020.2
}

UDC: $378.091 .3: 373.5 .011 .3-051$

PROFESSIONAL TRAINING OF THE FUTURE MUSIC TEACHER FOR CONCERTMASTER ACTIVITIES IN THE CLASS

\section{OF CLASSICAL DANCE}

\section{Ao Dengaova, Post-graduate student}

http://orcid.org/0000-0001-5882-8933

e-mail: dong0252@sina.com

National Pedagogical Dragomanov University, Kyiv, Ukraine

The article is devoted to the questions of a number of aspects of formation of skills of concertmaster activity as a component of piano preparation of the pianist-beginner in the class of classical choreography, revealing of the functional connections of the tandem teacherchoreographer - pianist-concertmaster, determination of the level of psychological-pedagogical students and performers interaction with the choreographer. The data are analyzed in the context of consideration of the general laws concerning the selection of the performing repertoire for musical design of classical choreography lessons, their importance, expediency and correspondence to the students' age characteristics, their level of musical perception.

Key words: concertmaster activities, beginner concert pianist, choreography art, classical dance, psychological and performance barriers, musical design.

аспірант, Ао Денгаова, Фахова підготовка майбутнього вчителя музики до концертмейстерської діяльності у класі класичного танцю / Національний педагогічний університет імені М. П. Драгоманова, Київ, Україна 
В статmі розглядається узагальнення ряду аспектів фрахової підготовки майбутніх учителів музики крізь призму психологопедагогічного та виконавського контексту в умовах практичної діяльності концертмейстера; формування умінь концертмейстерської діяльності як складової фортепіанної підготовки фрахівця у класі класичної хореографрії; з'ясуванні функціональних зв'язків в тандемі викладач-хореографр - піаністконцертмейстер; визначення рівня їх психолого-педагогічних та виконавських впливів і бар'єрів у музично-творчій комунікативній взаємодії.

Ключові слова: концертмейстерська діяльність, мистецтво хореографрії, класичний танець, хореографрічний тезаурус, психологовиконавські бар'єри, педагогічна взаємодія.

Вступ. Рефрормаційні процеси, що характеризують соціальноекономічне й суспільно-політичне життя України, вимагають трансформації системи мистецької освіти, зокрема фрахової підготовки майбутніх учителів музичного мистецтва. Саме заклади вищої освіти мають забезпечувати розвиток майбутніх учителів музичного мистецтва як особистостей, закладати підвалини їхньої подальшої самоосвіти, успішної самореалізації упродовж життя, підготувати до плідного профресійного розвитку в умовах Нової української школи.

Концептуальні засади сучасної мистецької освіти ґрунтовно розроблено українськими вченими-педагогами (В. Бутенко, Л. Василенко,
Л. Гаврілова,
Н. Гуральник,
О. Єременко,
А. Зайцева,
А. Козир,
О. Комаровська,
О. Устименко- Косоріч,
В. Лабунець,
Л. Масол,

Н. Миропольська,

О. Олексюк,

В. Орлов,

О. Отич,

Г. Падалка,

Л. Предтеченська, О. Реброва, О. Ростовський, О. Рудницька, Н. Сегеда, Т. Стратан-Артишкова, Т. Танько, О. Хижна, В. Черкасов, О. Щолокова та ін.). Широке коло питань, які піддавалися аналізу, зумовлене 
необхідністю їх розгляду в контексті фахової підготовки майбутніх учителів музичного мистецтва. Теоретико-методичні засади музичнопедагогічної освіти розглядали (Л. Масол, Г. Падалка, О. Ростовський, О. Рудницька, Л. Хлєбнікова, О. Щолокова та ін.), формування творчої активності студентів, профресійних якостей майбутніх фрахівців (Г. Кондратенко, Г. Ніколаї, Г. Шевченко, В. Шульгіна та ін).

Мистецтво третього тисячоліття відзначається розвитком синтетичних художніх фрорм, підсиленням тенденції до взаємопроникнення не лише різноманітних видів мистецтв, але й певним мутаціям в рамках кожного із них. Дослідники Г.Буш, І.Лосєв, І.Ляшенко, В.Медушевський та інші зазначають, що музичне мистецтво акумулює в собі загальнокультурну домінанту суспільства, яка віддзеркалює об’єктив суспільні потреби, що виникають на основі конкретного типу духовного простору їхнього побутування. Професор О.Хижна вважає, що музика як вид мистецтва має також «специфічну концептуальність, ідейний зріз якої розкриває всі вияви духовного життя суспільства, його інтелектуальний та соціально-психологічний потенціал, й водночас враховує постійну дію в ньому різних часових параметрів: реального, історичного, художнього»[1].

На зорі культурного розвитку людства мистецтво виникло як засіб спілкування. За умов відсутності сформованої мови основними засобами спілкування стали звук, ритм та дійство. 3 цієї синкретичної звукопластичної мови ритуалів пізніше виросли макрожанри, а потім і види мистецтва: танець, спів, декламація. І, безумовно, у візуальномедійному та мультимедійному контексті мистецтво хореограффії посідає чільне місце в інформаційно-видовищному континуумі сучасності. Хореографрія, як галузь мистецької діяльності, є однією 3 найскладніших проявів особистісно-творчого самовираження особистості майбутніх учителів. Безперечно, ця галузь діяльності 
виявляється у різних спеціалізаціях: класична (академічна), народна, сучасна, стилізована, спортивна, бальна тощо. Адже, незважаючи на широку популярність хореографічного мистецтва в різних його проявах, констатуємо, що в основі хореографії, як виду мистецької діяльності, лежить академічний, класичний танець, що передбачає різні напрями та трактування. Тому, виходячи 3 особливостей хореографрії як пластично-просторового виду мистецтва, на думкуА.Ваганової, варто зауважити, «що всі рухово-пластичні втілення беруть початок із класичної хореографії» [4]. Концертмейстер, як права рука хореографра-постановника, $€$ його другом-помічником у музичному оформленні мистецької пластичної дії.

\section{Аналіз останніх досліджень та публікацій.}

Дослідження мистецтва класичної хореографії як виду мистецької діяльності вже здавна проаналізовані в наукових розвідках та публікаціях видатних діячів XX ст. та сучасності:

1) в контексті розгляду фундаментальних засад хореографрічного мистецтва та методики викладання класичного танцю - А. Ваганової, €. Конорової, Л. Повалій, Л. Цвєткової;

2) методичних основ музичної організації та офрормлення уроків класичного танцю - О. Аксьонова, Т. Заборовської, В. Зоріна, Е. Мадьярової, Н. Ревської, Н. Сайко, Е. Халліуліної;

3) з позиції розгляду основних закономірностей практичної діяльності концертмейстера у класі класичної хореографії - О. Андрєєвої, Л. Бакало, І. Ваніної, О. Волосюк, Г. Вороніної, Є. Громової, О. Добротворської, С. Єгорової, Є. Корольової, І. Кравченко, К. Краснопьорової, В. Любимової, А. Луговської, О. Настюк, Л. Подпоріної, Н. Роденко, Т. Самарцевої, Н. Слупської, О. Фаїзової, Т. Чащиної, С. Шиврінської, Ж. Яковлєвої, Л. Ярмоловича; 
4) в контексті підбору музичного матеріалу з методичними вказівками для роботи концертмейстера в класі класичного танцю - Г. Безуглої, Л. Бучок, М. Добриніної, А. Каржубаєвої, Н. Майор, Л. Ярової;

5) проблеми взаємодії викладача хореографії та концертмейстера - Н. Голеншиної, О. Останіної, І. Тирпак, О. Черкасової, Т. Чернової та інших.

Метою статті $є$ розкриття основних закономірностей фрахової діяльності майбутнього вчителя музики у царині концертмейстерської діяльності у творчій взаємодії з викладачем хореографії у класі класичного танцю, обґрунтування психолого-виконавських аспектів поліфункціональності та багатогранності фаху концертмейстера, визначення основних фракторів підбору музичного репертуару для виконавського офрормлення занять з класичної хореографії.

Завдання дослідження полягають в узагальненні психологопедагогічного та виконавського аспектів фахової підготовки майбутніх учителів музичного мистецтва в умовах практичної діяльності концертмейстера; формування умінь концертмейстерської діяльності як складової фортепіанної підготовки фрахівця; з'ясуванні функціональних зв'язків в тандемі викладач-хореограф - піаністконцертмейстер; визначення рівня їх психолого-педагогічних та виконавських впливів, а також означення бар'єрів у музично-творчій комунікативній взаємодії..

Методологічну основу дослідження складають культурологічний підхід, з позицій якого своєрідність культури розглядалася в широкому розумінні як сукупність усієї духовно-матеріальної діяльності людини як в окремо взяті історичні періоди, так і впродовж усієї історії людства загалом; особистісно зорієнтований підхід, метою якого є фрормування унікальної індивідуальності; системно-цілісний підхід, ідеї якого відображалися при структуризації змісту, міждисциплінарних 
інтегративних зв'язків (фрілософрії, естетики, педагогіки, психології, фрахових дисциплін), враховуючи планування та здійснення у кожному 3 основних напрямів навчальної діяльності цілого комплексу освітніх та розвивальних завдань; діяльнісний підхід, спрямований на організацію інтенсивної практичної діяльності, адже саме через власну діяльність людина засвоює науку та культуру, способи пізнання про навколишній світ, формує та вдосконалює особистісні якості; компаративістський підхід, шо забезпечує процес гуманізації мистецької освіти, підвищення його інноваційності, креативності, інтегративності, створює сприятливі умови для фахового саморозвитку особистості в контексті розгляду загальних закономірностей щодо підбору виконавського репертуару для музичного офрормлення занять 3 класичної хореографії, їх важливості, доцільності та відповідності віковим особливостям вихованців (учнів), рівню їх музичному сприйманню і розвитку.

Окрім того, в даному дослідженні застосовано

Memod інтерпретаційно-аналітичного компаративу як механізму художньо-творчої інтелектуальної гнучкості піаніста-концертмейстера у класі класичної хореографії, що забезпечує та покращує якісне музичне втілення пластичних комбінацій на роялі (на інструменті) у часовому просторі. Розкрито особливості засвоєння структури побудови занять 3 класичного танцю (екзерсисів) піаністомконцертмейстером, вивчення хореографрічного тезаурусу, знаходження виконавських рішень хореографрічних рухів та вправ у процесі музичного виконання.

\section{Виклад основного матеріалу}

Основними показниками професійної майстерності майбутніх учителів музики передусім виділяють: особистісні якості, особливо перетворювальні й психологічні; усвідомлення ролі педагога у вихованні громадянина; безперервне підвищення загальної і 
професійної культури; пошукову діяльність педагога; володіння методами музичного навчання; конструювання власного музичнопедагогічного досвіду; результативність навчально-виховного процесу; активну просвітницьку діяльність, спрямовану на перетворення особистості учня й учителя.

Невід'ємну роль, вважає В.Зорін, у проведенні занять з класичної хореографрії посідає концертмейстер-піаніст, який втілює виконавські завдання та рішення в хореографрічну дійсність, руховий часопростір [6]. Відомо, що концертмейстерство в класі хореографії, чи то народній чи класичній, $€$ одним 3 найскладніших видів концертмейстерської діяльності. І завдяки цьому, ми можемо виділити основні здібності, якими повинен володіти концертмейстер-піаніст, а саме:

- здатність до осягнення та розуміння хореографрічного мистецтва як виду соціокультурної та видовищної діяльності;

- здатність до комплексного осягнення класичної хореографії в контексті музичного оформлення та втілення хореографічних комбінацій у руховому часопросторі, довершеності пластичних образів;

- оволодіння знаннями класичної гармонії, читки з листа, навичками імпровізації та виконавської інтерпретації академічних всесвітніх зразків музично-виконавського мистецтва у відповідності до характеру хореографрічних комбінацій та їх модуляційних різновидів;

- засвоєння складових побудов екзерсисів, їх варіативність та інтегративність в межах хореографрічної діяльності;

- засвоєння академічного хореографрічного тезаурусу (французька термінологія), виконавське оформлення хореографрічних вправ, ритмопластичних рухових образів;

- здатність підбирати доцільні та відповідні музичні зразки до інструментально-виконавської інтерпретації хореографрічних занять, що сприяють покращенню емоційного та психічно-музичного розвитку 
вихованців, їх м'язового тонусу, доцільність та правильність підбору музичного репертуару до занять з класичного танцю у відповідності до тієї чи іншої хореографічної побудови у пластичному часопросторі.

Приступаючи до зовсім нового виду діяльності - класичної хореографії, піаніст з наявним виконавським досвідом та комплексною фортепіанною підготовкою у класі класичної хореографії стикається 3 труднощами, які виникають у процесі музичного підбору та виконання інструментальних композицій. О.Останінп вважає, що це створює йому психолого-виконавські бар'єри у творчо-комунікативній взаємодії 3 викладачем-хореографом та вихованцями [10].

Тому, як показує практика, важливими рисами та якостями, якими має володіти піаніст-концертмейстер в класі класичної хореографії $€$ наступні:

1) усвідомлення свого функціонального призначення у класі класичного танцю. Важливо, з перших занять концертмейстеру відразу адаптуватись до нової сфери діяльності концертмейстерства як однієї з найскладніших ланок творчого самовираження особистості;

2) засвоєння та розуміння сутності побудови занять 3 класичного танцю, значущості кожного елементу у системі творчої взаємодії 3 викладачем хореографії (уклін, «хореографрічний розігрів», екзерсис біля станка, екзерсис на середині залу, adagio, класичні стрибки (allegro), вправи по діагоналі, гімнастичні вправи на землі). Від концертмейстера необхідними є: комплексне опанування структурних елементів та вивчення розмаїття танцювальних комбінацій, хореографрічного тезаурусу, їх місця у тих чи інших екзерсисах, видах і формах творчого виконання та модифрікації, ролі й призначення у загальній системі комплексного осягнення мистецтва класичної хореографiї; 
3) розуміння законів стилістики, мелодики, гармонії, фрразування, агогіки та артикуляції як основних засобів хореографічного втілення у звуковому часопросторі.

В залежності від виконання хореографрічних побудов в умовах доцільного відбору музичного репертуару концертмейстер-піаніст вже 3 перших занять має усвідомлено стилістично та творчо розробити принципи з відбору музичного репертуару. Це означає, що під час інструментально-музичного оформлення класичного танцю, концертмейстер має володіти глибинними знаннями 3 питань мелодики, гармонічних побудов, фрразування, інтерпретації та прагнути імпровізаційними засобами досягати розвитку звукової картини у візуально-просторову дійсність;

4) розуміння хореографрічного тезаурусу в співдружності: викладач -хореограф - піаніст-концертмейстер - вихованці хореографрічні комбінації.

5) засвоєння природи хореографрічного мистецького втілення на роялі пластичних вправ та класичних рухо-ритмо-образів. Це означає, що багатогранність, поліфункціональність та інтелектуальна творча гнучкість концертмейстера сприяє ефективному піднесеному пластично-руховому процесу в умовах гедоністичного та емоційного контексту учасників хореографрічного дійства;

6) координація та систематизація інтуїтивної та інтелектуальної гнучкості, уяви, уваги, візуально-просторового, слухового, музичнотеоретичного, звукового, тактильно-інтелектуального та гармонічного комплексів у виборі та розумінні інфрормації щодо осягнення та опанування техніками невербально-жестикуляційних образів у пластичному відтворенні хореографічних дій.

7) компромісність та деконфрліктність профресійних впливів та викликів системної взаємодії 3 питань розгляду музичного 
виконавського рішення класичних образів у процесі втілення хореографрічних вправ. Конфрлікт інтересів між викладачем хореографії та піаністом-концертмейстером може виникнути внаслідок суперечливих поглядів, які постають внаслідок певного непорозуміння та розділення музичних смаків і потреб, музичних уподобань, рівнобарв'я у відборі музичного репертуару (наприклад, demi plie 4/4 3/4). Подолання такого роду ситуацій та знаходження компромісу у вирішенні класичних завдань щодо музичного офрормлення тих чи інших рухообразів в системі класичного танцю вимагає неабиякої професійної аргументації, глибинної підготовки, педагогічно-творчої взаємодії та взаємопорозуміння. А це, в свою чергу, досягається в контексті гуманного й толерантного фрахового втілення комплексних підходів 3 наявними спільними точками дотику та опорою на профресіоналізм і власний виконавський досвід у вирішенні тих чи інших питань, які потребують грунтовного опрацювання;

8) осягнення та розуміння основних принципів та чирриків підбору музичного репертуару у відповідності до вікових та психологічних закономірностей, рівня музичного сприймання вихованців. Це досягається шляхом пошуків відповідних музичних зразків до інтерпретації хореографрічних рухо-образів у процесі занять 3 класичного танцю. При цьому, музичні зразки мають бути гармонійними, доступними та сприятливими для розуміння вихованців (виразна мелодична лінія, зрозуміле фразування, консонансна гармонія, контрастність образів, симетричність побудови);

9) вивчення та здійснення послідовних виконавських дій у подоланні концертмейстерських психологічних бар'єрів та труднощів музичного офрормлення у процесі хореографрічних занять (уникнення пауз, відпрацювання системності, послідовності в роботі, правильності 
та правдивості виконання на роялі музичного матеріалу в контексті втілення хореографрічних комбінацій в часопросторі).

Стикаючись з виконавськими труднощами на перших заняттях 3 класичного танцю, піаніст-концертмейстер повинен системно працювати над уникненням пауз під час виконання хореографрічних комбінацій з різними модифікаціями, довершеністю гармонії та музичної фррази (до прикладу, доречність та влучність гармонічно офрормити в найнеобхідніший момент завершення музичної фрази або композиції), що супроводжуються виразною жестикуляцією рухообразів у часопросторі та довершеністю хореографічної дії.

Важливе значення у оволодінні методологічними принципами та технологією концертмейстерської діяльності у класі класичного танцю відіграє підбір музичного репертуару до «хореографічного розігріву», екзерсисів біля станка та на середині залу, хореографічних вправ по діагоналі, adagio, класичних стрибків та піруетів (allegro) на середині залу та біля станка (на пуантах), виконання хореографрічних гімнастичних вправ на землі у відповідності до музичного метро-ритму композицій в контексті розгляду вікових особливостей вихованців, відповідність характеру виконання хореографічних комбінацій квадратної симетричної побудови.

На прикладі екзерсису біля станка та посередині залу, основоположними є такі головні риси, якими має керуватись концертмейстер при відборі музичного репертуару для виконання хореографічних комбінацій на роялі:

1) grand plie (demi plie) 2/4, 3/4, - повільна музика;

1a) temps lie $(2 / 4,4 / 4)$ - повільна плавна музика (виконується на середині залу);

2) battment tendu 2/4 - помірна уривчаста музика;

3) battment tendu demi plie 2/4 - помірна музика; 
4) battment tendu jete 2/4 - помірно-уривчаста музика;

5) rond de jambe par terre 2/4, 4/4 - повільна лірична музика;

6) battment fondu 4/4 - повільна ніжна музика;

7) battment frappe 2/4 - гостра помірна музика;

8) petit battment 2/4 - легка уривчаста музика;

9) releveljan developpe 4/4 - повільна широка музика;

10) grand battment jete - гостра маркована рухлива музика.

Ключове значення у підборі музичного репертуару до екзерсисів біля станка та на середині залу займає суттєва зміна музичного репертуару. Це означає, що концертмейстер-піаніст повинен чітко усвідомлювати та інтерпретувати зміну музичного репертуару у відповідності до виконання хореографічних комбінацій танцівниками в різних позиціях та їх модифрікаціях.

Відбір музичного репертуару до оформлення пластичної дії під час виконання екзерсисів біля станка та на середині залу піаністомконцертмейстером-початківцем вимагає:

- доступності сприймання музичного репертуару для вихованців;

- мелодійності та квадратності у побудові музичних фрраз;

- грунтовного вміння та здатності до класифікації музичного репертуару відповідно до психологічних та вікових особливостей вихованців, рівня їх музичного розвитку;

- виховання естетичних смаків, потреб та переконань щодо сприймання всесвітніх академічних, сучасних та джазових музичних зразків, що сприяють ефективному та насичено-емоційному піднесенню вихованців у процесі виконання хореографрічних комбінацій.

\section{Висновки}

Трансформації українського суспільства потребують подальших досліджень особливостей динаміки розвитку соціокультурної ситуації в Україні. А.Ленд'єл-Сяркевич та О. Хижна переконані, що сьогодення 
вимагає пошуку «системної організації суспільства, ієрархії смислів і фрормування художньої картини світу, ціннісних парадигм, зміни і видозміни ціннісних орієнтацій і систем цінностей молоді» [8]. Життя ставить перед учителем нові виклики і приносить нові мистецькі виміри, нові інтонації. Якщо вчитель музики хоче бути сучасним не лише у класі, на сцені, але й у використанні всіх можливостей сучасного музичного мислення, має бачити і підмічати у самій дійсності зародження і розвиток нових «фрарб», образних ресурсів, застосування інноваційних технологій у практиці фахової діяльності.

\section{Литература:}

1. Andreiko O., Savchenko R., Vasilenko L., Khizhna O., Savchenko Y.: (2019), Creative Cooperation of Subjects of the Educational Process in the Context of Musical Activity. Journal of History Culture and Art Research (ISSN: 2147-0626) Tarih Kültür ve Sanat Araştırmaları Dergisi . Vol. 8, No. 1, March.2019.

2. Безуглая Г. (2005), Концертмейстер балету: Музичний супровід уроку класичного танцю. Робота з репертуаром. СПб, 2005. 217 с.

3. Бучок Л., Ярова Л., Майор Н. (2010), Специфріка роботи концертмейстера на початковому етапі вивчення класичного танцю першого року навчання. Ужгород: Ґражда, 2010. 168 с.

4. Ваганова А. (2000), Основи класичного танцю. Вид.6. СПб: «Лань», 2000. 192с.

5. Громова Е., Шиврінська С. (2013), Акомпанемент на уроці класичного танцю як інструмент розвитку музикальності танцівника в сучасній хореографічній освіті. Вісник Череповецького державного університету. Мистецтвознавство. Череповецьк, 2013. №1. Т.2. С. 118 120.

6. Зорін В. (2018), Методичні аспекти роботи піаністаконцертмейстера у хореографічному класі. Науковий часопис НПУ 
імені М.П. Драгоманова. Серія 5. Педагогічні науки: реалії та перспективи. Київ, 2018. Вип.68. С. 42 - 45.

7. Казакова О. (2006), Урок класичного танцю (музичний посібник). Донецьк, 2006. 35 с.

8. O. Khyzhna, A.Lendel-Sarkevich. (2018), Peace Education as Arts Education: In Search of New Strategies// Philosophy and Cosmology, Volume 21 The Academic Journal ISSN 2518-1866 (Online), ISSN 23073705 (Print)

9. Настюк О. (2013), Особливості роботи концертмейстера на уроках класичного танцю. Вісник ЛНУ імені Тараса Шевченка. Львів, 2013. №10(269). Ч.II. С. 117 - 123.

10. Останіна О. (2019), Взаємодія концертмейстера і педагогахореографра на уроках класичного танцю. Науковий фрорум: Філологія, мистецтвознавство і культурологія: Матеріали XXII міжнародної наук.практ. конф. №1(22), М.: Вид. «МЦНО», 2019. С. 21 - 25.

11. Ревська Н. (2004), Класичний танець. Музика на уроці. Екзерсис. Методика музичного оформлення уроку класичного танцю. СПб: Композитор, 2004. 64 с.

12. Фаїзова О. (2017), Інноваційні методи підходу до роботи концертмейстера в класі хореографії. Методична розробка. Салават: Муніципальна бюджетна установа допоміжної освіти «Центр мистецтв» міського округу міста Салават Республіки Башкортостан, 2017. 13 с.

13. Цвєткова Л. (2011), Методика викладання класичного танцю. Київ: Альтерпрес, 2011. 324 с.

14. Ярмолович Л. (1967), Принципи музичного оформлення уроків класичного танцю. Л.: Музика, 1967. 144 с.

\section{References:}

1. Andreiko O., Savchenko R., Vasilenko L., Khizhna O., Savchenko Y.: (2019), Creative Cooperation of Subjects of the Educational Process in the 
Context of Musical Activity. Journal of History Culture and Art Research (ISSN: 2147-0626) Tarih Kültür ve Sanat Araştırmaları Dergisi . Vol. 8, No. 1, March.2019. (in English).

2. Bezuhlaia H. (2005). Kontsertmeister baletu: Muzychnyi soprovid uroku klasychnoho tantsiu. Robota z repertuarom. SPb. (in Russian).

3. Buchok L., Yarova L. and Maior N. (2010). Spetsyfika roboty kontsertmeistera na pochatkovomu etapi vyvchennia klasychnoho tantsiu pershoho roku navchannia. Uzhhorod: Grazhda. (in Ukrainian).

4. Vahanova A. (2000). Osnovy klasychnoho tantsiu. Vyd.6. SPb: «Lan».(in Russian).

5. Hromova E. and Shyvrinska S. (2013). 'Akompanement na urotsi klasychnoho tantsiu yak instrument rozvytku muzykalnosti tantsivnyka $v$ suchasnii khoreohrafichnii osviti'. [Accompaniment in the classical dance lesson as a tool for developing the dancer's musicality in modern choreographic education]. Visnyk Cherepovetskoho derzhavnoho universytetu. Mystetstvoznavstvo, no 1, T.2, pp. 118 - 120. (in Russian).

6. Zorin V. (2018). 'Metodychni aspekty roboty pianista-kontsertmeistera u khoreohrafichnomu klasi'. [Methodical aspects of the pianistconcertmaster's work in the choreographic class]. Naukovyi chasopys NPU imeni M.P. Drahomanova. Seriia 5. Pedahohichni nauky: realii ta perspektyvy. Kyiv, no.68, pp. $42-45$. (in Ukrainian).

7. Kazakova O. (2006). Urok klasychnoho tantsiu (muzychnyi posibnyk). Donetsk. (in Ukrainian).

8. O. Khyzhna, A.Lendel-Sarkevich.(2018). Peace Education as Arts Education: In Search of New Strategies// Philosophy and Cosmology, Volume 21 The Academic Journal ISSN 2518-1866 (Online), ISSN 23073705 (Print) (in English).

9. Nastiuk O. (2013). 'Osoblyvosti roboty kontsertmeistera na urokakh klasychnoho tantsiu'. [Features of the concertmaster at classical dance 
lessons]. Visnyk LNU imeni Tarasa Shevchenka. Lviv, no.10(269), p.II, pp. 117 - 123. (in Ukrainian).

10. Ostanina O. (2019). 'Vzaiemodiia kontsertmeistera i pedahohakhoreohrafa na urokakh klasychnoho tantsiu'. [Interaction of concertmaster and choreographer in classical dance lessons]. Naukovyi forum: Filolohiia, mystetstvoznavstvo i kulturolohiia: Materialy KhKhll mizhnarodnoi nauk.prakt. konf. no.1(22), M.: Vyd. «MTsNO», pp. 21 - 25. (in Ukrainian).

11. Revska N. (2004). Klasychnyi tanets. Muzyka na urotsi. Ekzersys. Metodyka muzychnoho oformlennia uroku klasychnoho tantsiu. SPb: Kompozytor. (in Russian).

12. Faizova O. (2017). Innovatsiini metody pidkhodu do roboty kontsertmeistera $\mathrm{v}$ klasi khoreohrafii. Metodychna rozrobka. Salavat: Munitsypalna biudzhetna ustanova dopomizhnoi osvity "Tsentr mystetstv» miskoho okruhu mista Salavat Respubliky Bashkortostan. (in Russian).

13. Tsvietkova L. (2011). Metodyka vykladannia klasychnoho tantsiu. Kyiv: Alterpres. (in Ukrainian).

14. Yarmolovych L. (1967). Pryntsypy muzychnoho oformlennia urokiv klasychnoho tantsiu. L.: Muzyka. (in Ukrainian).

Citation: Ao Dengaova (2020). PROFESSIONAL TRAINING OF THE FUTURE MUSIC TEACHER FOR CONCERTMASTER ACTIVITIES IN THE CLASS OF CLASSICAL DANCE. New York. TK Meganom LLC. Innovative Solutions in Modern Science. 8(44). doi: 10.26886/2414-634X.7(43)2020.2

Copyright: Ao Dengaova (C. 2020. This is an openaccess article distributed under the terms of the Creative Commons Attribution License (CC BY). The use, distribution or reproduction in other forums is permitted, provided the original author(s) or licensor are credited and that the original publication in this journal is cited, in accordance with accepted academic practice. No use, distribution or reproduction is permitted which does not comply with these terms. 